\title{
A SIGNER WRITES A LETTER IN VERSE
}

\author{
BY ORAL S. COAD
}

Professor Emeritus of English, Douglass College, Rutgers University

TN The Journal of the Rutgers University Library for June, 1945, appeared a cluster of poems, theretofore unpublished, by -Dr. James McHenry, a Baltimorean prominent in Revolutionary and subsequent affairs, both state and national. (His highest office was that of Secretary of War for a time under both Washington and John Adams.) One of these poems, in the form of a rhyming letter to Charles Carroll of Carrollton, was written in "the winter of the year I8I3" while McHenry was visiting at his son's home in Allegany County, off in the Maryland panhandle. These attractive stanzas expressed the author's pleasure in the solitudes and simplicities of the mountains where home-bred beef, venison, trout, and "water pure" abounded and where rattlesnakes, wolves, and bears were dangers much to be preferred to the "rogues and riot" of the town.

Together with the manuscripts of this and other McHenry poems, the Rutgers Library owns a hand-written copy of Carroll's verse epistle in reply. These lines were composed by one of the leading political figures of the Maryland of his time, who was known as the "First Citizen" of the state and the wealthiest man in the United States, though today he is remembered chiefly as one of the Signers of the Declaration of Independence. ${ }^{1}$

McHenry and Carroll, both convinced Federalists, had close political ties and were excellent friends and mutual admirers for many years. In I $800 \mathrm{McHenry}$ declared that Carroll was one of "the wisest, most prudent, \& best men in the United States." What Car-

${ }^{1}$ To distinguish himself from various relatives of the same name Charles Carroll regularly added "of Carrollton" to his signature, taking this designation from Carrollton Manor, a I 0 ,ooo-acre estate he owned in Frederick County. Actually he resided for the most part in or near Annapolis and Baltimore. Biographies are by Kate Mason Rowland, Life and Correspondence of Charles Carroll of Carrollton, 2 vols. (New York, 1898), and Ellen Hart Smith, Charles Carroll of Carrollton (Cambridge, 1942), the latter a delightfully written book.

${ }^{2}$ Bernard Christian Steiner, The Life and Correspondence of James McHenry (Cleveland, r907), p. 479. 
roll thought of McHenry is evident from his rhymed comments below. The friendship was all the more creditable to both men because McHenry was a staunch Presbyterian and Carroll a staunch Catholic.

Carroll's verse reply may deserve a little attention as one of the few surviving products of this once noted man's pen except for his extensive correspondence. Although now seventy-five years old and retired from active politics, he retained a lively interest in public affairs as well as social ones. Accordingly he found it difficult to understand why his friend, aged a mere fifty-nine, should seem to be withdrawn from life. Indeed as early as I 800, being greatly disturbed by President Adams" "shifting conduct" and the dangerous influence of revolutionary France, he wrote to McHenry: "Altho' your remaining rather a spectator of than an actor in the passing scene, is founded on a proper motive, yet you will find it impossible to retain a neutral character, nor do I think it fit you should: we ought all, each in our several spheres, to endeavour to set the public mind right, \& to administer antidotes to the poison that is widely spreading through the country."

At the time when the two verse letters were indited, the War of I 8 I2, which, as good Federalists, both men detested, was in full career. McHenry retired to the mountains. Carroll stayed on in the Baltimore area and denounced through his letters Madison's administration. When, in I 8 I 2, a pro-war mob in Baltimore destroyed the printing office of an anti-administration newspaper, killing one man and injuring several, McHenry rejoiced that he was comfortably out of it all in the wilds of Allegany County, while Carroll, remaining near the center of activity, continued to voice his deep concern and in his rhyming epistle counseled McHenry to return to the city and write, not on remote pastoral subjects, but on the burning problems of the day.

The Rutgers manuscript is not in the graceful Carroll handwriting to be seen on the Declaration of Independence; it may be a copy made by a member of the McHenry family. The poem appears in two parts separated by the initials and the date line, as indicated below. I have no explanation for the break or the change of pace,

${ }^{3}$ B. C. Steiner, op.cit., p. 476 . 
but the second part clearly continues the theme of the first and is obviously by the same author. The following is the complete reply Carroll addressed "To James M"Henry Esq", reprinted just as it was set down in the manuscript.

Dear is the lay unstudied \& undrest,

That breathes the comfort of a hermit blest,

From philosophick lore, who knows to reach

The summit of content \& wisely teach

By sound reflection after arduous toil,

A scorn of slander which may dare to soil

The well earned laurels that his merit claimed,

Boon of our Country! now by knaves defamed. ${ }^{4}$

If such the fate of Man! Tis more than even

Nine rogues in ten are damned where one's forgiven:

Then quit the Statesman be the Scholar Friend,

Nor heave a sigh how politiks may end.

Yet for a time when Science needs thine aid,

Leave meditations lonely mountain shade,

To bears \& wolves their gloomy forests give

And learn that life was given us - to live

$$
\mathrm{M}^{\mathrm{r}} \cdot \mathrm{C}-\mathrm{C}
$$

Baltimore

I $9^{\text {th }} \operatorname{Jan}^{\mathrm{y}}$ I 8 I 3

He's gone to the mountain he's lost to the City

$\mathrm{M}^{\mathrm{c}}$ Henry the jovial the gay \& the witty

Oh! sigh ye Librarians! oh weep all ye friends

No longer his converse your science extends

No more shall he aid ye in dressing a dish

No more play his part on your mutton \& fish

Ye shall droop o'er your pheasants your sallad \& wine

While he shall the myrtle \& laurel entwine

4 The reference here is probably to the hostility President Adams entertained toward his Secretary of War in 1800 , which led to violent language on Adams' part and a demand for McHenry's resignation. Thereafter he lived a life of retirement. (B. C. Steiner, op.cit., pp. 452-455, 458, 497.)

5 A possible allusion to McHenry's medical studies under Benjamin Rush and his service as an army surgeon at the beginning of the Revolution. 
In vales \& deep glens while he's hunting the deer Ye shall drop on the board sympathetic the tear Lamenting the hour to solitude given Allegany became to $\mathrm{M}^{\mathrm{c}}$ Henry his Heaven And you, ye fair ladies, presiding the while To grace at the table your welcome $\&$ smile Shall ye not regret the loss we deplore While round him the panthers \& tigers shall roar The gun of the hunter at distance is heard The wolf to your presence mild dames is prefer'd; And yet you must say with sincerity own From your sight none so courteous so polish'd has flow'n The Scholar the Genleman Washingtons friend On rattlesnakes even reflection can lend And force a fine Moral from fruits \& from flow'rs From woods herds \& flocks \& from cabins \& bowers Who likes all rurality [?] wild fowl \& trout, And to hear what his neighbours \& friends are about Who likes too his fare of beef, ven'son \& game, And the stream of pure water (forgotten to name)

Alass! the old wine is so scarce, I suspect We soon all his wisdom revers'd, may detect; Beleive me, he'll come from his mountain \& quiet, And write verses here, on the rogues \& the riot.

It is apparent that the Signer had little aptitude for poetry; his friend easily surpassed him in this respect. But perhaps he had the more commendable life philosophy of the two. And conceivably the disparate attitudes of the two Marylanders, both of whom suffered much from ill health, may help to explain why McHenry died at the age of sixty-two while Carroll lived on into his ninetysixth year. It was his conviction that "life was given us-to live." 